\title{
Does Phlebotomy for Donor Purposes in Healthy People Have Effects on Total Oxidant and Total Antioxidant Levels?
}

\section{Sağlıkıı İnsanlarda Donör Amaçlı Yapılan Flebotominin Total Oksidan ve Total Antioksidan Düzeylere Etkisi Var Mıdır?}

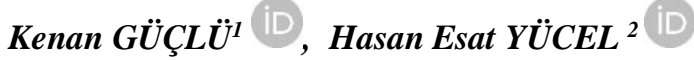

\section{$\underline{\underline{O Z}}$}

Amaç: Bu çalışmada, sağlıklı kişilerde yapılan flebotomi işleminin uzun dönemde vücut oksidan ve antioksidan sistem üzerindeki olası etkilerinin değerlendirilmesi amaçlanmıştır.

Araçlar ve Yöntem: Bu çalışma prospektif olarak tasarlanmış olup, çalışmaya Kızılay Kan Merkezine donör amaçlı kan bağışında bulunmak için başvuran sağlıklı ve gönüllü 30 kişi (15 erkek 15 kadın) dâhil edilmiştir. Flebotomi işlemi öncesinde ve işlemden sonraki 14. günde total antioksidan seviye, total oksidan seviye, oksidatif stres indeksi, hemoglobin, doymamıs demir baglama kapasitesi, demir ve ferritin düzeyleri ölçüldü.

Bulgular: İşlem öncesi ve işlemden sonraki 14. günde total antioksidan seviye, total oksidan seviye, oksidatif stres indeksi, hemoglobin, doymamış demir baglama kapasitesi ve demir değerleri istatistiksel olarak anlamlı değildi ( $\mathrm{p}>0.05$ ). İşlemden önceki hemoglobin ve ferritin değerleri ile 14. gündeki değerler anlamlı bulundu $(\mathrm{p}<0.001)$.

Sonuç: Tek defa yapılan flebotomi işleminin uzun dönemde vücut total oksidan ve total antioksidan düzeylerine etkisinin olmadığ 1 görünmektedir.

Anahtar Kelimeler: demir; flebotomi; oksidatif stres.

\section{ABSTRACT}

Purpose: In this study, we aimed to evaluate the possible long-term effects of phlebotomy on body oxidant and antioxidant system in healthy people.

Materials and Methods: This prospective study included 30 healthy volunteers (15 men and 15 women) who applied to donate blood to the Red Crescent Blood Center. Total antioxidant capacity, total oxidant status, oxidative stress index, hemoglobin, unsaturated iron binding capacity, iron and ferritin levels were measured before the phlebotomy and on the $14^{\text {th }}$ day following the procedure.

Results: The levels of total antioxidant capacity, total oxidant status, oxidative stress index, hemoglobin, unsaturated iron binding capacity, and iron values showed no statistically significant difference before and after the procedure ( $p>0.05)$. Hemoglobin and ferritin values showed statistically significant difference before and after the procedure.

Conclusion: It seems that single-season phlebotomy has no long-term effect on the body total oxidant and antioxidant levels.

Key Words: iron; oxidative stress; phlebotomy

Received: 15.06.2020; Accepted: 18.09.2020

${ }^{1}$ Kırşehir Training and Research Hospital, Department of Biochemistry, Kırşehir, Turkey.

${ }^{2}$ Kırşehir Training and Research Hospital, Department of Internal Medicine, Kırșehir, Turkey.

Corresponding Author: Dr. Öğr. Üyesi Kenan Güçlü, Kirsehir Training and Research Hospital, Department of Biochemistry, 40200, Kirsehir, Turkey.

e-posta: kguclu2001@ gmail.com

How to cite: Güçlü K, Yücel HE. Does phlebotomy for donor purposes in healthy people have effects on total oxidant and total antioxidant levels? Ahi Evran Med J. 2020;4(3):77-81. 


\section{INTRODUCTION}

Taking blood from the body for therapeutic purposes is a traditional procedure that has been practiced since ancient civilizations. Considering that donating blood heals illness, ancient civilizations have enabled the blood to move away from the body with many different methods. ${ }^{1}$ Today, phlebotomy procedure is carried out for two main purposes. The most common method is carried out with blood from healthy and voluntary blood donors to re-infuse blood (red blood cell suspension, fresh frozen plasma, etc.) to a specified or defined recipient. The other method of phlebotomy is therapeutic phlebotomy performed in primary and secondary polycythemia to reduce the excessive hemoglobin and hematocrit height and to remove excess iron load such as hemachromatosis. ${ }^{2}$

Disruption of the balance between the oxidant system and the antioxidant system in favor of oxidants is called oxidative stress. Increased free oxygen radical (FOR) production in the body with various physiological or environmental factors causes oxidative stress and subsequent cell damage. ${ }^{3}$ Iron and copper, which are metal ions, located in various oxidation steps under physiological conditions, act as catalysts by accelerating free radical reactions. Especially with the Fenton reaction, iron causes an increase in FOR production. These radicals, which are formed by oxidation, react with the structures of cells such as lipid, protein, DNA, and cause diseases such as diabetes, cardiovascular diseases and cancer. ${ }^{4-6}$ The positive effect of reducing iron load and oxidative stress in the body with phlebotomy for therapeutic purposes has been shown in many studies. ${ }^{7-12}$ However, studies on the effect of phlebotomy, which is performed in healthy individuals for blood donation, on oxidative stress levels are limited. Phlebotomy, which is performed regularly in healthy people, can reduce FOR production. Reducing the oxidative stress which is present in the physiopathology of many chronic diseases can help to prevent possible diseases. A study by Yunce et al showed that in people who donated blood, super oxide dismutase levels increased and pentraxin3 and c-reactive protein (CRP) levels decreased 24 hours after phlebotomy ${ }^{12}$. We evaluated total antioxidant capacity
(TAC), total oxidant level (TOS) and oxidative stress index (OSI) levels in order to show the long-term results of phlebotomy treatment in healthy and voluntary individuals and to evaluate possible effects on the body oxidant and antioxidant system.

\section{MATERIALS AND METHOD}

\section{Study Population}

The study was conducted in Kırşehir Training and Research Hospital between February 2020 and April 2020. 30 healthy volunteers (15 females, 15 males) who applied to Kırşehir Red Cresent for blood donation for phlebotomy were included in the study. While individuals were included in the study, the criteria of the Red Crescent institution were taken into consideration, and also smokers, the individuals who took multivitamins or antioxidants were excluded from the study. After phlebotomy was applied for donor purposes, volunteers were followed up. People who had to use medication such as analgesics or who had an acute infection attack were not included in the study. The study was approved local ethics committee (Approval number:202003/30, Date: 25/02/2020) and informed consents were obtained from all the participants.

\section{Collection of Blood Samples}

Blood samples were obtained through venipuncture to routine biochemistry tubes and tubes containing $\mathrm{K}_{2}$ EDTA just before the procedure and on the $14^{\text {th }}$ day following the procedure. The blood was placed for $30 \mathrm{~min}$ at room temperature before the centrifugation (3000 rpm/10 $\mathrm{min}$ ). The serum samples were stored at $-80^{\circ} \mathrm{C}$ until the time of analyses of TAC and TOS. Approximately 400-500 cc blood was collected by phlebotomy.

\section{Measurement of TAC and TOS}

Hemoglobin levels were determined with autoanalyzer (Sysmex Corporation, Kobe, Japan); TAC, TOS levels were measured using Rel Assay brand commercial kits (Rel Assay 
Kit Diagnostics, Gaziantep, Turkey) on autoanalyzer (Cobas c501, Roche Diagnostic Corp., Mannheim, Germany).

OSI value was calculated as the following formula;

OSI $=[(\mathrm{TOS}, \mu \mathrm{mol} H 2 \mathrm{O} 2 \mathrm{Eq} / \mathrm{l}) /(\mathrm{TAC}, \mu \mathrm{mol}$ Trolox Eq/l) $\times 100]$.

\section{Statistical analysis}

Statistical analysis of the data was performed using the SPSS 21.0 software package and Power analysis G-Power 3.1.9.4. Power analysis $(\alpha=0.05$, Effect size $=0.50$, Power $(1-\beta)=$ 0.80) was performed to determine the total sample size. Distributions were evaluated by using One Sample Kolmogorov Smirnov and Shapiro-Wilk tests. Results are expressed as mean \pm standard deviation, Median (25th percentile -75 th percentile). Differences were regarded as significant at $\mathrm{p}<0.05$.

\section{RESULTS}

The mean age of 30 people included in the study was 33.63 \pm 13.12 , and body mass index (BMI) mean was $25.20 \pm 3.94$. In the study $50 \%$ of the participants were male and $50 \%$ were female.

Explanatory statistics of the values of TAC, TOS, OSI, Hemoglobin (Hgb), Unsaturated Iron Binding Capacity (UIBC), Iron and Ferritin belonging to 30 people before the procedure and on the 14th day of phlebotomy are presented in Table 1.

Table 1. Descriptive statistics of the variables

\begin{tabular}{|c|c|c|c|}
\hline Variables & $\begin{array}{c}\text { Before } \\
\text { Phlebotomy }\end{array}$ & $\begin{array}{l}\text { After } \\
14 \text { days }\end{array}$ & $\begin{array}{c}P \\
\text { values }\end{array}$ \\
\hline $\begin{array}{l}\text { Total antioxidant status, } \\
\text { (mmol Trolox Equiv./L) }\end{array}$ & $1.98 \pm 0.15$ & $1.98 \pm 0.16$ & 0.844 \\
\hline $\begin{array}{l}\text { Total oxidant status, } \\
(\mu \mathrm{mol} \mathrm{H} 2 \mathrm{O} 2 \text { Equiv./L) }\end{array}$ & $\begin{array}{l}8.27 \\
(6.01 \sim 10.74)\end{array}$ & $\begin{array}{l}9.24 \\
(7.57 \sim 12.37)\end{array}$ & 0.199 \\
\hline $\begin{array}{l}\text { Oxidative stress index, } \\
\text { (ABSUs) }\end{array}$ & $\begin{array}{l}413.0 \\
(308.0 \sim 511.25)\end{array}$ & $\begin{array}{l}463.5 \\
(383.25 \sim 575.0)\end{array}$ & 0.221 \\
\hline Hemoglobin, $(\mathrm{g} / \mathrm{dL})$ & $16.34 \pm 1.45$ & $15.14 \pm 1.58$ & $<0.001$ \\
\hline $\begin{array}{l}\text { Unsaturated Iron Binding } \\
\text { Capacity, }(\mu \mathrm{g} / \mathrm{dL})\end{array}$ & $268.2 \pm 62.0$ & $280.0 \pm 97.2$ & 0.418 \\
\hline Iron $(\mu \mathrm{g} / \mathrm{dL})$ & $90.0 \pm 31.1$ & $88.3 \pm 50.2$ & 0.862 \\
\hline Ferritin (ng/mL) & $64(31.5 \sim 98.0)$ & $29(19.5 \sim 64.5)$ & $<0.001$ \\
\hline
\end{tabular}

When Table 1 is examined, it is seen that we found no significant difference between TAC, TOS, OSI, UIBC and Iron values before the procedure and on the 14 th day $(p>$ 0.05). Although there is a numerical increase in TOS and OSI values on the 14th day after the procedure, this increase is not significant. The difference between the $\mathrm{Hgb}$ and ferritin values before the procedure and the values on the 14th day is significant $(\mathrm{p}<0.001)$.

\section{DISCUSSION}

This study is the first study in which the body total oxidant and total antioxidant system were evaluated as long-term in healthy volunteers who underwent phlebotomy. In our study, we found that the phlebotomy procedure applied in healthy individuals did not affect body TAC levels after 14 days. There was a relative increase in TOS and OSI levels, however, it was not significant

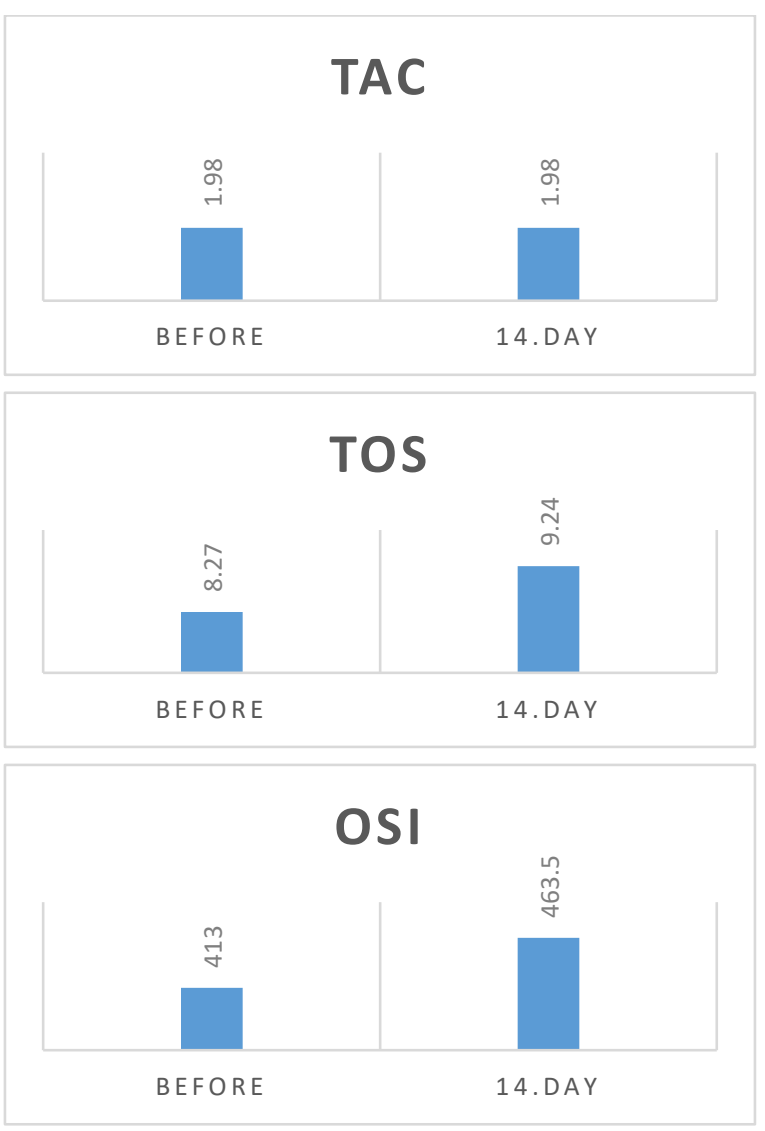

TAC: Total antioxidant capacity, TOS: Total oxidant status, OSI: Oxidative stress index

Figure 1. Graphical representation of TAC, TOS, OSI mean values. 
Yunce et al. observed in their study that phlebotomy procedure reduced acute phase reactants and increased superoxide dismutase (SOD) level in the short term (24 hours later), however, in our study, we found that it had no efficacy in the longer term (14 days). ${ }^{12}$

In primary and secondary polystymes with excessive hemoglobin and hematocrit levels, and in diseases such as hemacromatosis with an excessive iron height, the primary treatment is to eliminate the underlying cause. ${ }^{13}$ Additionally, when rbc and iron is removed from the body with therapeutic phlebotomy it provides an effective method in managing disease symptoms and complications. The purpose of therapeutic phlebotomy in such diseases is to reduce red blood cells and serum iron. ${ }^{13}$ Therapeutic phlebotomy application provides relief of symptoms and also reduces probable organ damage which is caused by high serum iron levels. ${ }^{14}$ Approximately 225-250 mg of heme iron is extracted with $500 \mathrm{ml}$ whole blood donation. ${ }^{15}$ Iron is vital for most living things and has an important role in cellular functions. Iron's toxicity stems from iron's tendency to form oxygen radicals that ultimately causes cell damage. ${ }^{15}$ Iron has the capacity to easily import and export electrons. With this feature, it has an important function in the body, especially in cytochrome systems. On the other hand, iron is biochemically hazardous; it can indirectly damage protein, lipid and DNA by Fenton reaction. ${ }^{16}$ In the studies conducted in the literature, it was observed that iron was removed from the body with maintenance phlebotomy treatment and it was beneficial in the course of many diseases. Yano et al. have shown that maintenance phlebotomy therapy suppresses the progression of iron-induced liver fibrosis in chronic hepatitis C. ${ }^{17}$ A large-scale study found that regular phlebotomy reduced the risk of acute myocardial infarction in middleaged men. ${ }^{7}$ With regular phlebotomy applied to people with peripheral artery disease, Zacharski et al. showed that potential cancer and mortality associated with it may decrease. ${ }^{8}$ Houschyar et al. suggested that oxidative stress catalyzed by iron deposition plays a role in the pathogenesis of metabolic syndrome. They showed that regular blood donation improves clinical presentation in patients with metabolic syndrome, resulting in improved cardiovascular risk and glycemic control markers. ${ }^{9}$ Dwyer BE et al. showed in their study that the reduction of increased blood iron stores with phlebotomy improves the clinical picture of Alzheimer's disease. ${ }^{10}$ In a study by Durmus et al., TOS, OSI and malondialdehyde (MDA) levels, which are oxidative stress parameters, have been shown to be significantly high in Polistemia vera patients. With phlebotomy treatment, TOS, OSI and MDA values were found significantly lower in patients than pre-treatment values. ${ }^{11}$ Rajpathak et al. suggested that the decrease in iron levels in the body caused by phlebotomy can increase insulin sensitivity in humans.

A positive relationship has been reported between the circulating ferritin level and the risk of other insulin-resistant conditions, such as type 2 diabetes and metabolic syndrome, gestational diabetes, and polycystic ovary syndrome. ${ }^{18}$ The fact that maintenance phlebotomy effectively benefits many diseases suggests the idea that it may prevent the formation of chronic diseases caused by oxidative stress that may occur in the future in healthy individuals. In addition, people who donate blood declare that their life comfort increases after they donate blood and that they are more vigorous and active during the day supports this idea.

Our study has two main limitations. First, this was a singlecenter study. Second, low number of patients consisted of healthy volunteers may not fully reflect the population. More studies should be carried out to regularly monitor donors' blood pressure and phlebotomy's impact on cholesterol levels.

In our study, although there was a significant decrease in hemoglobin and ferritin levels with one-time phlebotomy, there was no significant decrease in serum iron and iron binding capacity. The absence of this reduction can be explained by iron transfer from ferrite, which is an iron depot, to plasma for use in hemoglobin synthesis by compensatory physiological mechanisms. The main purpose and vital importance of phlebotomy in healthy people is to obtain blood and blood product materials. In addition, there are many benefits such as blood pressure, hyperlipidemia, atherosclerotic vascular diseases, and easier regeneration of 
cellular elements (leukocyte, erythrocyte and platelet). ${ }^{15}$ Therefore, in order to promote blood donation, studies involving multi-centered and wider participants are needed to observe the effects on both the oxidant parameters and the immune system.

\section{Conflicts of Interest}

The authors declare no conflicts of interest.

\section{REFERENCES}

1. Parapia LA. History of bloodletting by phlebotomy. Br J Haematol. 2008;143(4):490-495.

2. Zivot A, Lipton JM, Narla A, Blanc L. Erythropoiesis: insights into pathophysiology and treatments in 2017. Mol Med. 2018;24(1):11.

3. Rahal A, Kumar A, Singh V, et al. Oxidative stress, prooxidants, and antioxidants: the interplay. Biomed Res Int. 2014. Article ID:761264

4. Valko M, Rhodes CJ, Moncol J, Izakovic M, Mazur M. Free radicals, metals and antioxidants in oxidative stressinduced cancer. Chem Biol Interact. 2006;160(1):1-40.

5. Poprac P, Jomova K, Simunkova M, Kollar V, Rhodes CJ, Valko M. Targeting Free Radicals in Oxidative Stress-Related Human Diseases. Trends Pharmacol Sci 2017;38(7):592-607.

6. Kattoor AJ, Pothineni NVK, Palagiri D, Mehta JL. Oxidative Stress in Atherosclerosis. Curr Atheroscler Rep. 2017;19(11):42.

7. Salonen JT, Tuomainen TP, Salonen R, Lakka TA Nyyssonen K. Donation of blood is associated with reduced risk of myocardial infarction. The Kuopio
Ischaemic Heart Disease Risk Factor Study. Am J Epidemiol. 1998;148(5):445-451.

8. Zacharski LR, Chow BK, Howes PS, et al. Decreased cancer risk after iron reduction in patients with peripheral arterial disease: results from a randomized trial. J Natl Cancer Inst. 2008;100(14):996-1002.

9. Houschyar KS, Ludtke R, Dobos GJ, et al. Effects of phlebotomy-induced reduction of body iron stores on metabolic syndrome: results from a randomized clinical trial. BMC Med. 2012;10:54.

10. Dwyer BE, Zacharski LR, Balestra DJ, et al. Getting the iron out: phlebotomy for Alzheimer's disease? Med Hypotheses. 2009;72(5):504-509.

11. Durmus A, Mentese A, Yilmaz M, et al. The thrombotic events in polycythemia vera patients may be related to increased oxidative stress. Med Princ Pract. 2014;23(3):253-258.

12. Yunce M, Erdamar H, Bayram NA, Gok S. One more health benefit of blood donation: reduces acute-phase reactants, oxidants and increases antioxidant capacity. J Basic Clin Physiol Pharmacol. 2016;27(6):653-657.

13. Sposi NM. Oxidative Stress and Iron Overload in $\beta$ Thalassemia: An Overview. Zakaria M., editor. Beta Thalassemia. UK;IntechOpen;2019

14. Kim KH, Oh KY. Clinical applications of therapeutic phlebotomy. J Blood Med. 2016;7:139-144.

15. Cook LS. Therapeutic phlebotomy: a review of diagnoses and treatment considerations. J Infus Nurs. 2010;33(2):81-88

16. Emerit J, Beaumont C, Trivin F. Iron metabolism, free radicals, and oxidative injury. Biomed Pharmacother. 2001;55(6):333-339.

17. Yano M, Hayashi H, Wakusawa S, et al. Long term effects of phlebotomy on biochemical and histological parameters of chronic hepatitis C. Am J Gastroenterol. 2002;97(1):133-137.

18. Rajpathak SN, Crandall JP, Wylie-Rosett J, Kabat GC, Rohan TE, Hu FB. The role of iron in type 2 diabetes in humans. Biochim Biophys Acta. 2009;1790(7):671-681. 